\title{
Pengaruh Kesadaran Wajib Pajak, Pengetahuan Perpajakan dan Kualitas Pelayanan Fiskus terhadap Kepatuhan Wajib Pajak dalam Membayar Pajak Hotel di Kabupaten Buleleng
}

\author{
Kadek Vanny Panji Putra1* ${ }^{*}$ Edy Sujana ${ }^{2}$ iD \\ ${ }^{123}$ Program Studi S1 Akuntansi, Universitas Pendidikan Ganesha, Singaraja, Bali, Indonesia \\ * kadek.vanny.panji.putra@undiksha.ac.id ${ }^{1 *}$
}

\section{Abstrak}

Penelitian ini bertujuan untuk mengetahui pengaruh kesadaran wajib pajak terhadap kepatuhan wajib pajak, pengetahuan perpajakan terhadap kepatuhan wajib pajak, dan kualitas pelayanan fiskus terhadap kepatuhan wajib pajak. Penelitian ini merupakan penelitian kuantitatif dengan jumlah responden sebanyak 35 karyawan bagian keuangan pada Hotel di Kabupaten Buleleng. Data diperoleh dengan penyebaran kuesioner secara langsung. Teknik sampel yang digunakan yaitu purposive sampling. Data yang digunakan adalah data primer berupa jawaban responden dan diolah menggunakan SPSS 20 for windows. Hasil penelitian menunjukkan bahwa kesadaran wajib pajak berpengaruh positif dan signifikan terhadap kepatuhan wajib pajak, pengetahuan perpajakan berpengaruh positif dan signifikan terhadap kepatuhan wajib pajak dan kualitas pelayanan fiskus berpengaruh secara positif dan signifikan terhadap kepatuhan wajib pajak.

Kata Kunci : Kesadaran Wajib Pajak, Kepatuhan Wajib Pajak, Kualitas Pelayanan Fiskus dan Pengetahuan Perpajakan

\section{Abstract}

This study aims to determine the effect of taxpayer awareness on taxpayer compliance, tax knowledge on taxpayer compliance, and the fiscus service quality on taxpayer compliance. This research is a quantitative research with the number of respondents as many as 35 employees of the financial division of hotels in Buleleng Regency. Data obtained by distributing questionnaires directly. The sample technique used is purposive sampling. The data used are primary data in the form of respondents' answers and processed using SPSS 20 for windows. The results showed that taxpayer awareness had a positive and significant effect on taxpayer compliance, tax knowledge had a positive and significant effect on taxpayer compliance and fiscus service quality had a positive and significant effect on taxpayer compliance.

Keywords: Taxpayer Awareness, Taxpayer Compliance, Fiscus Service Quality and Tax Knowledge

\section{Pendahuluan}

Sebagai salah satu unsur penerimaan negara, pajak memiliki peran yang semakin diandalkan untuk membiayai pengeluaran pemerintahan (Supadmi, 2009). Undang-undang No 32 Tahun 2004 tentang Pemerintahan Daerah menyebutkan bahwa pengembangan otonomi pada daerah kabupaten dan kota diselenggarakan dengan memperhatikan prinsipprinsip demokrasi, peran serta masyarakat, pemerataan, dan keadilan serta memperhatikan potensi dan keanekaragaman Daerah. Tujuan dilaksanakannya otonomi daerah adalah untuk meningkatkan kemandirian daerah dan mengurangi ketergantungan fiskal terhadap pemerintah pusat. Dalam meningkatkan kemandirian suatu daerah, sangat besar kaitannya dengan meningkatkan Pendapatan Asli Daerah (PAD) salah satunya dengan cara mengelola PAD secara ekonomis, efisien dan efektif.

Berdasarkan lembaga pemungutnya, pajak bisa diklasifikasikan menjadi pajak pusat serta daerah. Kedua hal tersebut merupakan dua hal yang tak sama akan tetapi mungkin untuk

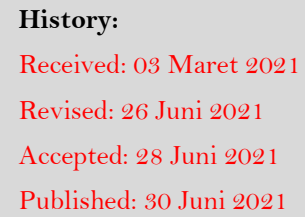

Publisher: Undiksha Press

Licensed: This work is licensed under

a Creative Commons Attribution 3.0 License

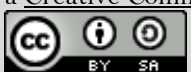


wajib pajak kesulitan dalam membandingkannya. Pajak pusat atau kerap disebut pajak negara merupakan pajak yang dikelola pemerintah pusat (Direktorat Jenderal Pajak atau DJP) yang digunakan dalam mendanai pengeluaran rutin negara serta pembangunan (APBN). Lalu pajak daerah ialah kontribusi wajib dari Orang Pribadi ataupun Badan yang memiliki sifat memaksa dengan dasar UU yang berlaku yang digunakan dalam mendanai pengeluaran serta pembangunan daerah (APBD) dan diatur oleh Pemda. Jenis pajak yang dipungut dari pajak pusat serta daerah pun tak sama. Pajak pusat mengelola jenis pajak contohnya Pajak Penghasilan (PPh) serta Pajak Pertambahan Nilai (PPN). Sementara pajak daerah mengelola 11 jenis pajak, contohnya: Pajak Hotel, Pajak Hiburan, Pajak Restoran, dsb.

Peran pajak, baik pusat maupun daerah sangat berpengaruh sebagai peningkatan pemasukan baik Negara maupun daerah, akan tetapi belum maksimal terlihat pada tak sedikitnya wajib pajak yang taktaat ketika membayar pajak. Kepatuhan wajib pajak di Indonesia bisa dilihat melalui tax ratio. Tax ratio pada 2016 adalah 10,8\% sedangkan ketika 2017 menurunan menjadi 10,7\%, dan ketika tahun 2018 meningkat sebesar 11,5\%. Tahun 2019 tax ratio menurun sangat drastis bahkan lebih kecil dari tahun 2016 yakni menjadi 10,7\% (Kemenkeu.go.id, 2019). Direktur Penyuluhan, Pelayanan, \& Humas Dirjen Pajak Hestu Yoga Saksama memaparkan alasan menurunnya tax ratio dikarenakan keadaan perekonomian Indonesia sedang tak bagus. Seperti diketahui, tax ratio di Indonesia masihlah sangat rendah apabila disandingkan dengan Negara di Asia Pasifik (Cnnindonesia.com, 2020).

Fenomena penurunan penerimaan pajak terjadi pada pajak daerah di Kabupaten Buleleng khususnya pajak hotel. Realisasi pajak daerah di Kabupaten Buleleng meleset. Hingga penghujung tahun 2019, realisasi pajak daerah hanya mencapai 89,18 persen saja. Sejumlah komponen pajak, seperti pajak hotel dan pajak restoran, meleset cukup banyak dari perencanaan awal.Pada tahun 2019 lalu, target pajak daerah yang diberikan mencapai Rp 174,65 miliar.

Faktanya, hingga 31 Desember 2019 lalu, realisasi pajak daerah baru mencapai Rp 155,75 miliar atau 89,18 persen dari target. Sisa Rp 18,89 miliar, dipastikan gagal terealisasi.Sejumlah komponen yang gagal mencapai target yakni pajak penerangan jalan, pajak hotel, pajak restoran, dan pajak hiburan. Pajak penerangan jalan hanya terealisasi Rp 39,39 miliar atau sekitar 69,91 persen dari target Rp 56,35 miliar.Pajak hotel, dari target Rp 33,84 miliar hanya terealisasi Rp 28,92 miliar atau 85,44 persen dari target. Pajak restoran hanya terealisasi Rp 16,44 miliar atau 90,9 persen dari target Rp 18,09 miliar. Sedangkan pajak hiburan hanya terealisasi $\mathrm{Rp} 1,87$ miliar atau 65,11 persen dari target Rp 2,87 miliar.Kepala Badan Keuangan Daerah (BKD) Buleleng Gede Sugiartha yang dikonfirmasi tak menampik bahwa target pajak daerah meleset (radarbali.jawapos.com, 2019).

Kepatuhan wajib pajak dapat disebabkan bermacam faktor contohnya faktor seperti faktor internal serta eksternal. Faktor internal ialah faktor dari individu seorang wajib pajak yang berkaitan terhadap karakterisktik selaku sebab atau alasan ketika melaksanakan kewajiban perpajakan. Lalu, faktor eksternal ialah faktor dari luar diri seorang wajib pajak, contohnya lingkungan atau situasi yang terdapat di sekitar wajib pajak (Rahmawaty, 2014). Cara meningkatkan kepatuhan wajib pajak hotel dapat dilakukan melalui beberapa faktor diantaranya kesadaran wajib pajak, pengetahuan perpajakan, sosialisasi perpajakan dan pelayanan Fiskus. Beberapa faktor tersebut sering dijadikan tolok ukur peningkatan kepatuhan wajib pajak dalam membayar pajak. Apabila ada upaya peningkatan kesadaran wajib pajak, pengetahuan perpajakan, sosialisasi perpajakan dan pelayanan Fiskus diharapkan akan berdampak pada kepatuhan wajib pajak hotel dalam membayar atau melunasi kewajibannya sehingga penerimaan dari pajak daerah dapat terus meningkat setiap tahunnya.

Dalam meningkatkan kepatuhan wajib pajak diperlukan juga pemahaman pengetahuan perpajakan oleh wajib pajak itu sendiri. Pengetahuan memiliki peran yang signifikan karena 
sulit bagi wajib pajak dalam menjalankan kewajiban pajaknya apabila wajib pajak kurang memahami tata cara pembayaran pajak. Penelitian sebelumnya menunjukkan bahwa pengetahuan pajak penting dalam rangka meningkatkan tingkat kepatuhan pajak (Richardson, 2006: 89). Artinya, wajib pajak lebih bersedia untuk mematuhi aturan dan ketentuan yang berlaku jika mereka memahami konsep dasar perpajakan. Menurut Ekawati dan Endro (2008) Pemahaman tersebut meliputi: pengisian Surat Pemberitahuan (SPT) secara benar, penghitungan pajak sesuai dengan Pajak terutang yang ditanggung oleh WP, sehingga WP harus memiliki pemahaman yang cukup dalam menghitung pajak terutang dan membayar secara tepat waktu sesuai dengan peraturan perundang-undangan. Wajib pajak harus memiliki pengetahuan yang cukup mengenai hal-hal yang berkaitan dengan kewajiban wajib pajak.

Apabila wajib pajak memiliki pengetahuan yang cukup mengenai pemenuhan wajib pajak maka kepatuhan pembayaran pajak dapat dilakukan dengan baik oleh Wajib Pajak. Kurangnya sosialisasi tentang tata cara pemenuhan kewajiban perpajakan bagi Wajib Pajak menjadi salah satu faktor rendahnya pengetahuan masyarakat tentang pentingnya peranan pajak dalam pembangunan negara yang pada akhirnya membuat masyarakat enggan untuk memberikan kontribusi yang semestinya sehingga berdampak pada kurang patuhnya masyarakat dalam membayar pajak. Salah satu cara untuk meningkatkan pengetahuan masyarakat tentang perpajakan adalah melalui pendidikan perpajakan formal maupun non formal.

Kesadaran wajib pajak adalah contoh faktor internal yang dapat memberikan pengaruh tinggi rendahnya kepatuhan dari wajib pajak ketika pembayaran pajak. Menumbuhkan kesadaran perpajakan bagi sebagian memang tidak mudah. Bahkan pada contoh kasus lain mereka cenderung meloloskan diri dari kewajiban membayar pajak. Menurut Suryarini dan Turmudji (2010) ada banyak faktor yang menyebabkan tingkat kesadaran masyarakat masih rendah diantaranya adalah kurangnya informasi dari pemerintah kepada rakyat,adanya kebocoran dalam sistem penerimaan pemungutan pajak,malas,dan tidak adanya timbal balik secara langsung dari pemerintah.

Cara pemungutan pajak yang sesuai juga mempengaruhi wajib pajak dalam kewajibannya membayar pajak. Pemungutan pajak memang merupakan sesuatu yang tidak mudah, dbutuhkan peran aktif antara wajib pajak dan pemerintah agar dapat terciptanya pelayanan pajak yang nyaman dan optimal. Selain itu pengetahuan masyarakat tentang perpajakan harus dioptimalkan aik melalui sosialiasi ataupun melalui pendidikan karakter. Karena secara tidak langsung dengan pengetahuan wajib pajak diharapkan para wajib pajak sadar akan kewajibannya dalam membayar pajak karena pajak berguna bagi kebutuhan bersama demi membangun suatu negara yang makmur dan sejahtera.

Selain itu, faktor internal dalam memberikan pengaruh pada kepatuhan wajib pajak dapat juga dilihat melalui faktor eksternalnya yakni kualitas pelayanan. Kualitas pelayanan yang diberikan membuat wajib pajak merasa puas/senang atas apa yang dilayani kepada mereka. Pemberian pelayanan yang baik dapat meningkatkan kepatuhan wajib pajak dalam membayar pajak secara sukarela (Putri dan Jati, 2013). Peningkatan kualitas dan kuantitas pelayanan diharapkan dapat meningkatkan kepuasan pada wajib pajak sebagai pelanggan sehingga meningkatkan kepatuhan dalam bidang perpajakan (Supadmi, 2009). Pelayanan yang berkualitas bukan hanya pelayanan yang diberikan oleh Fiskus saja tetapi melainkan pelayanan didalam ruangan seperti kenyaman dalam melakukan kewajibannya dan kenyaman semua fasilitas yang disediakan oleh kantor pembayaran pajak masing-masing.

Berdasarkan pemaparan permas dialahan tersebut peneliti tertarik untuk menjadikan wajib pajak Hotel di Kabupaten Buleleng sebagai objek penelitian.. Alasan peneliti memilih wajib pajak hotel Kabupaten Buleleng karena berdasarkan informasi BPKPD Kabupaten Buleleng terjadi kesenjangan antara target dengan realisasi dari penerimaan pajak restoran di 
Kabupaten Buleleng pada 2016-2019. Berdasarkan pemaparan diatas, adapun tujuan dari penelitian ini adalah untuk mengetahui pengaruh kesadaran wajib pajak,pengetahuan perpajakan, kualitas pelayanan fiskus terhadap kepatuhan wajib pajak hotel.

Grand Theory pada penelitian ini yaitu, Theory of Planned Behavior (TPB) adalah hasil pengembangan teori sebelumnya Fishbein \& Ajzen pada 1975 yaitu Theory of Reasoned Action (TRA). TRA dibuat memakai asumsi dasar bahwasanya manusia bersikap secara sadar serta mempertimbangkan semua informasi yang ada, dan pada TPB ditambah lagi variabel yang belum ada dan diaplikasikan di TRA yakni kontrol perilaku yang dipersepsikan. Dalam (Asfa, 2017) TPB memaparkan perilaku individu yang muncul dikarenakan niat berperilaku tersebut serta niatan tersebut muncul dikarenakan faktor-faktor internal serta eksternal. Sikap individu pada perilaku berkaitan dengan kepercayaan terhadap sebuah perilaku, evaluasi hasil perilaku, norma subyektif, kepercayaan normatif serta motivasi agar taat.

Dalam penelitian ini, TPB dianggap berkaitan dalam memaparkan faktor-faktor yang memberi pengaruh patuh tidaknya wajib pajak pada perilakunya dalam pemenuhan kewajiban perpajakan. Sebelum seseorang melaksanakan suatu hal, pastinya mempunyai keyakinan terkait hasil yang nantinya didapatkan dari perilaku terkait yang membuat individu terkait memilih akan melaksanakan ataupun tak melaksanakan hal tersebut. Hal tersebut memiliki kaitan terhadap kesadaran wajib pajak. Wajib pajak yang sadar pajak, mempunyai keyakinan terkaitpenting tidaknya pembayaran pajak dalam membantu penyelenggaraan pembangunan daerah (behavioral beliefs).

Kesadaran WP terhadap perpajakan sangat penting dalam peningkatan kepatuhan WP dalam pemenuhan kewajibannya. Kesadaran pembayaran pajak pada TPB di penelitian ini selaku minat berprilaku (behavior intention). Berdasar penelitian Kusuma (2016) menunjukkan kesadaran wajib pajak berpengaruh positif pada kepatuhan wajib pajak hotel di Kabupaten Klungkung. Berdasarkan hal tersebut maka dirumuskan hipotesis sebagai berikut: $H_{1}$ : Kesadaran Wajib Pajak berpengaruh positif terhadap Kepatuhan Wajib Pajak

Pada penelitian Rimawati (2013) menyimpulkan bahwa selain pengetahuan pajak, pemahaman dan kesadaran wajib pajak menjadi sangat penting untuk mempengaruhi tingkat kepatuhan wajib pajak. Berdasar uraian tersebut dirumuskan hipotesis berikut :

$\mathrm{H}_{2}$ : Pengetahuan Perpajakan Berpengaruh Positif Terhadap Kepatuhan Wajib Pajak

Sucandra dan Supadmi (2016) menjelaskan bahwa Fiskus haruslah selalu memberi pelayanan yang berkualitas pada wajib pajak supaya mampu memberikan kepuasan serta kepatuhan ketika menjalankan kewajiban perpajakannya sehingga melalui pelayanan yang berkualitas wajib pajak semakin taat menjalankan kewajiban. Berdasar uraian tersebut didapat hipotesis sebagai berikut :

$H_{3}:$ Kualitas Pelayanan Fiskus Berpengaruh Positif Terhadap Kepatuhan Wajib Pajak

\section{Metode}

Penelitian yang digunakan dalam penelitian ini adalah penelitian kuantitatif. Sumber data yang digunakan yakni, data primer dengan menggunakan kuesioner dalam proses pengumpulan data. Penelitian ini dilakukan pada Wajib pajak hotel di Kabupaten Buleleng.

Sampel adalah bagian dari jumlah dan karakteristik yang dimiliki oleh populasi (Sugiyono, 2014). Teknik pengambilan sampel yang digunakan adalah purposive sampling dimana merupakan suatu teknik pengambilan sampel berdasarkan keperluan penelitian dimana individu yang diambil dari populasi dipilih secara sengaja melalui beberapa pertimbangan. 
Jumlah sampel yang digunakan yaitu 35 wajib pajak hotel di Kabupaten Buleleng. Teknik pengambilan sampel dalam penelitian ini menggunakan purposive sample. Variabel penelitian ini, yaitu kesadaran wajib pajak, pengetahuan perpajakan, kualitas pelayanan fiskus sebagai variabel bebas, sedangkan kepatuhan wajib pajak sebagai variable terikat. Peneliti mengumpulkan data menggunakan kueisoner yang disebarkan secara langsung ke Hotel-hotel yang terdaftar sebagai wajib pajak yang terpilih menjadi sampel di Kabupaten Buleleng. Jawaban responden akan diukur menggunakan skala likert.

Dilakukan pengumpulan data dan jika telah terkumpul diuji terlebih dahulu menggunakan uji statistik deskriptif, lalu dengan uji validitas dan reliabilitas untuk mengetahui kualitas data. Selanjutnya, uji asumsi klasik yang terdiri dari uji normalitas, uji heteroskedastisitas, dan uji multikolinieritas serta menggunakan uji hipotesis dengan menggunakan uji t, uji regresi linier sederhana, dan uji koefisien determinasiof data analysis

\section{Hasil dan Pembahasan}

Proses yang pertama yaitu uji statistik deskriptif untuk mengetahui skor maksimum, skor minimum, nilai rata-rata dan standar deviasi pada variabel. Nilai standarDdeviasi pada seluruh variabel menunjukkan angka sebesar 2,745 pada variabel $\mathrm{X}$, dan 2,032 pada variabel Y. Dilihat dari hasil tersebut, standarDdeviasi lebihKkecil dari skorRrata-rata di setiap variabel yaitu sebesar 42,72 pada variabel X, dan 27,55 pada Y. Hal ini menandakan bahwa respon terhadap setiap variabel bervariasi atau dengan kata lain terjadi perbedaan nilai penerapan sistem e-budgeting dan transparansi pengelolaan keuangan daerah terhadap nilai rata-rataasebesar nilai standar deviasi pada tiap variabel. Hasil Uji statistik deskriptif dapat disajikan pada tabel 1 berikut.

Tabel 1. Hasil Uji Statistik Deskriptif

\begin{tabular}{lccccc}
\hline & N & Min & Max & Mean & Std. Deviation \\
\hline Kesadaran Wajib Pajak (X1) & 35 & 18 & 24 & 21.00 & 2.249 \\
\hline Pengetahuan Perpajakan (X2) & 35 & 18 & 24 & 21.09 & 2.393 \\
\hline Pelayanan Kualitas Fiskus (X3) & 35 & 33 & 41 & 37.06 & 2.155 \\
\hline Kepatuhan Wajib Pajak (Y) & 35 & 18 & 24 & 21.06 & 2.437 \\
\hline Valid N (listwise) & 35 & & & & \\
\hline
\end{tabular}

Sumber : Data Diolah (2020)

Kemudian dilakukan uji validitas dan uji reliabilitas untuk mengetahui kualitas data dalam penelitian. Hasil uji validitas kesadaran wajib pajak (X1), terdapat 6 item yang tersedia, pengetahuan perpajakan (X2), terdapat 6 item, kualitas pelayanan fiskus (X3) terdapat 12 item dan semua item dinyatakan valid. Pada variabel lainnya yaitu kepatuhan wajib pajak hotel (Y) dengan 6 item pernyataan, dan dinyatakan valid maka seluruh item dapat digunakan untuk uji selanjutnya.

Kemudian dilakukan uji bahwa variabel Kepatuhan Wajib Pajak (Y) memiliki nilai Cronbach Alpha sebesar 0,868, variabel Kesadaran Wajib Pajak (X1) memiliki nilai Cronbach Alpha sebesar 0,840, variabel Pengetahuan Perpajakan (X2) memiliki nilai Cronbach Alpha sebesar 0,935, variabel Pelayanan Kualitas Fiskus (X3) memiliki nilai Cronbach Alpha sebesar 0,852 dapat dikatakan bahwa semua variabel dikatakan reliabel karena nilai tersebut lebih besar dari 0,50. Menurut Susetyo, 2011 menyatakan data dikatakan reliable saat mencapai sekurang-kurangnya memperoleh koefisien korelasi sebesar 0,50.

Selanjutnya dilakukan uji asumsi klasik. Pertama adalah uji normalitas dengan ujiKolmogorov-Smirnov (K-S) untuk mengetahui apakah data tersebut berdistribusi normal atau tidak. Kriteria yang digunakan yaitu dengan melihat berdasarkan probabilitas (Asymtotic 
Significant) yaitu jika probabilitas > 0,05 maka distribusi dari populasi dinyatakan normal, dan jika probabilitas $<0,05$ maka data dikatakan tidak berdistribusi normal. Hasil menunjukkan Komogorov-Smirnov yaitu sebesar 0,585 dan nilai Asymp. Sig. (2-tailed) sebesar 0,884 berarti nilai tersebut lebih besar dari 0,05. Sehingga dalam hal ini dapat dikatakan data terdistribusi secara normal.

Kemudian dilakukan uji multikolinearitas. Nilai yang umum digunakan untuk menunjukan model regresi yang bebas dari multikoliniearitas adalah nilai VIF $<10$ dan nilai tolerance > 0,1. Hasil menunjukkan menunjukkan bahwa nilai tolerance pada variabel Kesadaran Wajib Pajak (X1) sebesar 0,262 lebih besar dari 0,1 dan nilai VIF sebesar 3,816 lebih kecil dari 10 dapat dikatakan variabel X1 tidak terjadi multikolinearitas. Variabel Pengetahuan Perpajakan (X2) memiliki nilai tolerance 0,279>0,1 dan nilai VIF 3,587<10 berarti variabel X2 tidak terjadi multikolinearitas. Variabel Pelayanan Kualitas Fiskus (X3) memiliki nilai tolerance $0,506>0,1$ dan VIF 1,977 < 10 dapat dikatakan variabel X3 tidak terjadi multikolinearitas. Jadi, nilai tolerance pada semua variabel independen berada di atas 0,1 dan nilai VIF berada di bawah 10 sehingga dapat disimpulkan setiap variabel terbebas dari multikolinearitas.

Uji terakhir dari asumsi klasik adalah uji heteroskedastisitas. Cara yang digunakan untuk mendeteksi heteroskedastisitas adalah dengan uji Glejser. Apabila tingkat signifikansi $<0,05$ maka dikatakan terdapat heteroskedastisitas, sedangkan disaat tingkat signifikansi > 0,05 maka dikatakan data terbebas dari heteroskedastisitas. Hasil menunjukkan bahwa nilai signifikansi dari variabel Kesadaran Wajib Pajak (X1) sebesar 0,080>0,05 berarti dinyatakan bahwa tidak terjadi heteroskedastisitas. Variabel Pengetahuan Perpajakan (X2) memiliki tingkat signifikansi sebesar 0,351>0,05 berarti tidak terjadi heteroskedastisitas. Variabel Pelayanan Kualitas Fiskus (X3) memiliki tingkat signifikansi sebesar 0,253>0,05 berarti dapat dikatakan tidak terjadi heteroskedastisitas.

Data penelitian telah lulus uji asumsi klasik, maka seluruh variabel dapat dilanjutkan ketahap uji berikutnya. Kemudian dilakukann uji analisis regresi linear berganda. Pengujian ini dilakukan untuk mengetahui pengaruh dua atau lebih variabel independen terhadap satu variabel dependen. Berikut tabel yang menunjukkan hasil uji analisis regresi linear berganda. Hasil analisisis regresi linear berganda disajikan pada tabel 2 sebagai berikut.

Tabel 2. Hasil Uji Analisis Regresi Linier Berganda

\begin{tabular}{llrrr}
\hline Model & \multicolumn{2}{c}{$\begin{array}{c}\text { Unstandardized } \\
\text { Coefficients }\end{array}$} & $\begin{array}{c}\text { Standardized } \\
\text { Coefficients }\end{array}$ \\
\cline { 3 - 5 } & & B & Std. Error & Beta \\
\hline 1 & (Constant) & -6.569 & 2.645 & .280 \\
\cline { 2 - 5 } & Kesadaran Wajib Pajak & .303 & .130 & .493 \\
\cline { 2 - 5 } & Pengetahuan Perpajakan & .502 & .119 & .255 \\
\cline { 2 - 5 } & Pelayanan Kualitas Fiskus & .288 & .098 & \\
\hline
\end{tabular}

Sumber : Data Diolah (2020)

Berdasarkan model regresi linear berganda, dapat diinterpretasikan sebagai berikut.

1. Konstanta pada tabel yaitu sebesar $-6,569$ berarti besarnya Kepatuhan Wajib Pajak yaitu -6,569 dengan mengesampingkan pengaruh besarnya Kesadaran Wajib Pajak (X1), Pengetahuan Perpajakan (X2), dan Pelayanan Kualitas Fiskus (X3).

2. Nilai koefisien regresi variabel Kesadaran Wajib Pajak (X1) sebesar 0,303 berarti dapat dikatakan bahwa jika terjadi peningkatan pada variabel Kesadaran Wajib Pajak (X1) sebesar satu satuan dengan asumsi variabel lain bernilai konstan, maka besarnya nilai Kepatuhan Wajib Pajak (Y) akan meningkat sebesar 0,303.

3. Nilai koefisien regresi variabel Pengetahuan Perpajakan (X2) sebesar 0,502 berarti dapat dikatakan bahwa jika terjadi peningkatan pada variabel Pengetahuan Perpajakan 
(X2) sebesar satu satuan dengan asumsi variabel lain bernilai konstan, maka besarnya nilai Kepatuhan Wajib Pajak (Y) akan meningkat sebesar 0,502.

4. Nilai koefisien regresi variabel Pelayanan Kualitas Fiskus (X3) sebesar 0,228 berarti dapat dikatakan bahwa jika terjadi peningkatan pada variabel Pelayanan Kualitas Fiskus (X3) sebesar satu satuan dengan asumsi variabel lain bernilai konstan, maka nilai Kepatuhan Wajib Pajak (Y) akan meningkat sebesar 0,228.

Berdasarkan dari model analisis regresi linear berganda diatas dapat diinterpretasikan bahwa Konstanta sebesar -6,569 mengandung arti bahwa nilai konsisten variabel kepatuhan wajib pajak adalah sebesar $-6,569$.

Koefisien regresi (X1) sebesar 0,303, (X2) sebesar 0,502, (X3) sebesar 0,288. Koefisien regresi tersebut bernilai positif, sehingga dapat dikatakan bahwa arah pengaruh variabel (X1) kesadaran wajib pajak, (X2) pengetahuan perpajakan, (X3) kualitas pelayanan fiskus terhadap (Y) kepatuhan wajib pajak hotel adalah positif.

Dilanjutkan dengan uji hipotesis yakni uji koefisien determinasi yang menjelaskan.seberapa besarnya pengaruh-variabel independent (X) terhadap variabelddependen (Y). Nilai koefisien determinasi dapat dilihat pada R Square.KKoefisien determinasi memiliki nilai kisaran00 sampai dengan 1. Apabila koefisienddeterminasi sama dengan $=0$ maka variabel independentdinyatakan tidak memiliki pengaruh pada variabelldependen. Jika koefisien determinasi samadengan $=1$ berarti dapat dikatakan variabel independent berpengaruh pada variabel dependent. Hasil koefisien determinasi dalam penelitian ini dapat>dilihat pada tabel 3

Tabel 3. Hasil Uji Koefisien Determinasi

\begin{tabular}{ccccc}
\hline Model & R & $\begin{array}{c}\text { R } \\
\text { Square }\end{array}$ & Adjusted R Square & $\begin{array}{c}\text { Std. Error of the } \\
\text { Estimate }\end{array}$ \\
\hline 1 & $.939^{\mathrm{a}}$ & .882 & .871 & .876 \\
\hline
\end{tabular}

Sumber : Data Diolah (2020)

Berdasarkan yang telah dipaparkan pada tabel 3, menunjukkan nilai koefisien determinasi (R Square) sebesar 0,882 (diperoleh dari pengkuadratan nilai R yaitu $(0,939) 2$ ). Nilai koefisien determinasi sebesar 0,882 sama dengan 88,2\%. Sehingga variabel Kesadaran Wajib Pajak (X1), Pengetahuan Perpajakan (X2), dan Pelayanan Kualitas Fiskus (X3) bepengaruh terhadap Kepatuhan Wajb Pajak (Y) sebesar 88,2\% dan sisanya yaitu 11,8\% dipengaruhi oleh variabel lain di luar model regresi tersebut. Uji hipotesis selanjutnya yaitu uji t. Pengujian hipotesis (uji t) Ddigunakan untuk menguji seberapa besar variabel independen berpengaruh dalam menerangkan variasi variabel dependen. Dalam uji ini digunakan $\alpha=5 \%(0,05)$ dengan ketentuan apabila nilai probabilitas signifikansi $t>\alpha$, maka $\mathrm{H} 0$ diterima dan $\mathrm{H} 1$ ditolak. Jika nilai probabilitas sig. $\mathrm{t}<\alpha$, maka $\mathrm{H} 0$ ditolak sehingga H1 dapat diterima.

Pada Uji t didapat bahwa variabel kesadaran wajib pajak (X1), pengetahuan perpajakan (X2), kualitas pelayanan fiskus (X3) memiliki nilai signifikansi $<0,05$ dengan t hitung sebesar berarti dapat dikatakan bahwa kesadaran wajib pajak (X1), pengetahuan perpajakan (X2), kualitas pelayanan fiskus (X3) memiliki pengaruh positif serta signifikan terhadap kepatuhan wajib pajak hotel (Y).

\section{Pengaruh Kesadaran Wajib Pajak terhadap Kepatuhan Wajib Pajak}

Berdasarkan uji hipotesis (uji t), variabel Kesadaran Wajib Pajak memiliki nilai signifikansi sebesar 0,027 lebih kecil dari 0,05 serta t hitung sebesar 2.332 lebih besar dari 2,0395 (t tabel), berarti H0 ditolak dan H1 diterima sehingga dapat dikatakan bahwa 
Kesadaran Wajib Pajak (X1) berpengaruh secara positif (nilai B positif sebesar 0,303) dan signifikan terhadap Kepatuhan Wajib Pajak Hotel. Hal ini menunjukkan semakin tinggi Kesadaran Wajib Pajak maka akan semakin baik Kepatuhan Wajib Pajak itu sendiri.

Hasil penelitian ini sejalan dengan penelitian yang dilakukan oleh Suryani dan Saleh (2018) yang menyatakan bahwa Kesadaran Wajib Pajak, Berpengaruh Signifikan Terhadap Kepatuhan Pengusaha Hotel Dalm Membayar Pajak Hotel Di Kota Banda Aceh. Selain itu penelitian menurut Jaya dan Jati (2016) juga menyatakan Kesadaran Wajib Pajak berpengaruh positif dan signifikan terhadap Kepatuhan Wajib Pajak Dalam Membayar Pajak Restoran Di Dinas Pendapatan Kota Denpasar. Bentuk pengaruh variabel kesadaran wajib pajak terhadap tingkat kepatuhan wajib pajak orang pribadi adalah positif. Hal ini berarti apabila kesadaran wajib pajak meningkat, menyadari akan kewajibannya, maka akan meningkatkan pula tingkat kepatuhan dalam memenuhi kewajibannya yakni patuh membayar pajak tepat waktu

\section{Pengaruh Pengetahuan Perpajakan terhadap Kepatuhan Wajib Pajak}

Berdasarkan uji hipotesis (uji t), variabel Pengetahuan Perpajakan memiliki nilai signifikansi sebesar 0,000 lebih kecil dari 0,05 serta t hitung sebesar 4,226 lebih besar dari 2,0395 (t tabel), berarti H0 ditolak dan H1 diterima sehingga dapat dikatakan bahwa Pengetahuan Perpajakan (X2) berpengaruh secara positif (nilai B positif sebesar 0,502) dan signifikan terhadap Perilaku kepatuhan wajib pajak. Hal ini menunjukkan semakin tinggi atau kuatnya Pengetahuan Perpajakan maka akan semakin baik Kepatuhan Wajib Pajak tersebut.

Hasil penelitian ini sesuai dengan konsep atau teori TPB dari pengembangan TRA oleh Fishbein \& Ajzen pada 1975. Sebelum seseorang melaksanakan suatu hal, tentu individu terkait akan berpikir terlebih dahulu sebelum bertindak. Pemikiran yang dimiliki individu ini terkait dengan pengetahuan yang dimilikinya dengan mempertimbangkan semua informasi yang ada. Pengetahuan yang dimiliki individu nantinya akan menghasilkan perilaku yang membuat individu memilih akan melaksanakan ataupun tak melaksanakan hal tersebut. Sama kaitannya terhadap pengetahuan perpajakan. Disaat wajib pajak memiliki pengetahuan yang cukup mngenai pajak, maka akan berpengaruh pada perilakunya dalam pemenuhan kewajiban perpajakan. Dikatakan bahwa secara parsial Pengetahuan Perpajakan internal berpengaruh signifikan terhadap keputusan membayar pajak sehingga hal ini mempengaruhi kepatuhan wajib pajak hotel di kabupaten Buleleng.

\section{Pengaruh Kualitas Pelayanan Fiskus terhadap Kepatuhan Wajib Pajak}

Berdasarkan uji hipotesis (uji t), variabel Variabel Pelayanan Kualitas Fiskus (X3) memiliki nilai signifikansi sebesar $0,006<0,05$ dengan $t$ hitung sebesar 2,939 2,0395 dan dilihat dari nilai B yaitu sebesar 0,288 berarti dapat dikatakan bahwa Pelayanan Kualitas Fiskus (X3) berpengaruh secara positif dan signifikan terhadap Kepatuhan Wajib Pajak (Y). Hal ini menunjukkan semakin tinggi Kualitas Pelayanan Fiskus maka akan semakin tinggi kepatuhan wajib pajak hotel.

Hasil penelitian ini sesuai dengan konsep grand theory TPB yakni perilaku patuh (compliance) wajib pajak sangatlah dipengaruhi pertimbangan-pertimbangan rasionalitas terkait sikap, norma subjektif serta kontrol perilaku yang dipersepsikan (Asfa, 2017). Pada hal ini sikap atau perilaku wajib pajak dapat dipengaruhi orang lain yaitu pelayanan fiskus. Keputusan taat pajak ini berkaitan dengan kualitas pelayanan Fiskus yang memberikan motivasi dari pihak eksternal untuk wajib pajak berperilaku patuh terhadap kewajibannya dalam membayar pajak. 


\section{Simpulan dan Saran}

Berdasarkan hasil penelitian dan pembahasan yang telah dilakukan, maka dapat disimpulkan yaitu hasil uji hipotesis menunjukkan nilai signifikansi kesadaran wajib pajak adalah 0,027 lebih kecil dari 0,05 dengan t hitung sebesar 2,322 lebih besar dari t tabel sebesar 2,0395 dan nilai b sebesar 0,303 yang menunjukkan bahwa kesadaran wajib pajak berpengaruh positif dan signifikan terhadap kepatuhan wajib pajak, sehingga hipotesis 1 dapat diterima, hasil uji hipotesis menunjukkan nilai signifikansi pengetahuan perpajakan adalah 0,000 lebih kecil dari 0,05 dengan t hitung sebesar 4,226 lebih besar dari t tabel sebesar 2,0395 dan nilai b sebesar 0,502 artinya pengetahuan perpajakan berpengaruh positif dan signifikan terhadap kepatuhan wajib pajak, sehingga hipotesis 2 dapat diterima, hasil uji hipotesis menunjukkan nilai signifikansi kualitas pelayanan fiskus adalah 0,006 lebih kecil dari 0,05 dengan $t$ hitung sebesar 2,939 lebih besar dari t tabel sebesar 2,0395 dan nilai $b$ sebesar 0,288 yang artinya kualitas pelayanan fiskus berpengaruh positif dan signifikan terhadap kepatuhan wajib pajak, sehingga hipotesis 3 dapat diterima.

Adapaun saran dari peneliti terkait dengan penelitian ini yaitu pemerintah daerah kabupaten buleleng yang memiliki hak untuk melalukan pemungutan pajak di wilayah kabupaten buleleng, diharapkan lebih meningkatkan kesadaran wajib pajak hotel dengan melakukan kegiatan sosialisasi, edukasi, dan kegiatan monitoring kepada wajib pajak sehingga nantinya pemasukan daerah dari pajak yang dibayarkan akan semakin meningkat. indikator dalam variabel kualitas pelayanan fiskus yang paling mempengaruhi dalam penelitian ini adalah bukti fisik hasil penelitian ini bisa dijadikan acuan bagi bpkpd kabupaten buleleng untuk semakin meningkatkan pelayanannya. respon atau tanggapan yang cepat dari fiskus dalam membantu masalah yang dihadapi wajib pajak sangat diperlukan karena akan mempengaruhi tingkat kepatuhan wajib pajak, sehingga perhatian dan kemudahan harus terus ditingkatkan demi kenyamanan wajib pajak. selain meningkatkan pelayanan fiskus perlu dimbangi dengan peningkatan sanksi yang tegas agar wajib pajak semakin patuh dalam membayar pajak. penelitian ini hanya menggunakan tiga variabel bebas yaitu kesadaran wajib pajak $\left(\mathrm{x}_{1}\right)$, pengetahuan perpajakan $\left(\mathrm{x}_{2}\right)$ dan kualitas pelayanan fiskus $\left(\mathrm{x}_{3}\right)$. untuk meningkatkan kualitas penelitian, peneliti menyarankan agar peneliti selanjutnya menggunakan variabel yang berbeda ataupun menambahkan lagi variabel lainnya yang lebih kompleks serta memilikki kebaruan penelitian disbanding penelitian-penelitian yang ada sebelumnya. peneliti selanjutnya dapat menambahkan variabel baru yang sesuai dengan karakteristik daerah dan membandingkan data antar daerah lainnya. dari beberapa keterbatasan yang telah peneliti paparkan, diharapkan peneliti selanjutnya dapat memperbaiki keterbatasan-keterbatasan di atas..

\section{Daftar Pustaka}

Ademarta, Rio Septiadi. 2013. Pengaruh Modernisasi Sistem Administrasi Perpajakan Terhadap Tingkat Kepatuhan Pengusaha Kena Pajak di Kantor Pelayanan Pajak (KPP) Pratama Padang dan Solok. Skripsi Sarjana Jurusan Akuntansi pada Fakultas Ekonomi Universitas Negeri Padang, Sumatera Barat. Albawaba. 2013. Kazakhstan - Tax Administration Project Reform (JERP). http://search.proquest.com/docview/1365300761 ?accountid=32506. Diunduh tanggal 26, November 2015.

Alfiah, Irma., (2014), “Kesadaran wajib Pajak, sanksi Pajak, Sikap Fiskus, Lingkungan Pajak, Pengetahuan Akan Perpajakan, Persepsi Atas Efektifitas Sistem Perpajakan, Kemauan Membayar Pajak Terhadap Kepatuhan wajib Pajak Orang Pribadi di DPPKAD Grobogan Purwodadi, Skripsi, Fakultas Ekonomi Universitas Muria Kudus. 
Christina, Ni Kadek, dan Putu Kepramareni. 2012. Pengaruh Kewajiban Moral, Kualitas Pelayanan dan Sanksi Perpajakan pada Kepatuhan Wajib Pajak dalam Membayar Pajak Kendaraan Bermotor di Kantor Bersama Samsat Denpasar. Jurnal Riset Akuntansi, Vol 2 No 2: p137-150.

Dewi, Septiana Putu dan I Made Sukartha. 2015. Faktor-Faktor yang mempengaruhi kepatuhan wajib pajak dalam membayar hotel. E-Jurnal Akuntansi Universitas Udayana Vol.13.No.2.

Dharma, Gede Pani Esa dan Ketut Alit Suardana. 2014. Pengaruh Kesadaran Wajib Pajak, Sosialisasi Perpajakan, Kualitas Pelayanan Pada Kepatuhan Wajib Pajak. E-Jurnal Akuntansi Universitas Udayana 6.1 (2014): 340-353.

Dinas Pendapatan Kota Denpasar. 2015. Profil Dinas Pendapatan Kota Denpasar. http://www.pendapatan.denpasarkota.go.id/ diakses tanggal 26 bulan 4 tahun 2015 pukul 21:50 Wita.

Febri, Angky. 2011. Analisis Pengaruh Kualitas Pelayanan dan Pengetahuan Perpajakan Terhadap Kepatuhan Wajib Pajak Orang Pribadi Pada Kantor Pelayanan Pajak Pratama Bandung. E-Jurnal. Unicom.

Fikriningrum, Winda Kurnia dan Muchamad Syafruddin. 2012. Analisis Faktor- Faktor Yang Mempengaruhi Wajib Pajak Orang Pribadi Dalam Memenuhi Kewajiban Membayar Pajak (Studi Kasus Pada Kantor Pelayanan Pajak Pratama Semarang Candisari). Dalam Journal Of Accounting Vol.1, No.2, Hal.1-15. Jurusan Akuntansi Fakultas Ekonomika dan Bisnis Universitas Diponegoro.

Fitria, Dona. 2017. Pengaruh Kesadaran Wajib Pajak, Pengetahuan Dan Pemahaman Perpajakan Terhadap Kepatuhan Wajib Pajak. Journal of Applied Business and Economics, Vol. 4 No. 1.

Fuadi, Arabella Oentari dan Yenni Mangoting. 2013. Pengaruh Kualitas Pelayanan Petugas Pajak, Sanksi Perpajakan dan Biaya Kepatuhan Pajak Terhadap Kepatuhan Wajib Pajak UMKM. Tax \& Accounting Review, Vol.1, No.1 Program Akuntansi Pajak Program Studi Akuntansi Universitas Kristen Petra.

Indriantoro, Nur dan Bambang Supomo. 2002. Metodologi Penelitian Bisnis untuk Akuntansi dan Manajemen. Yogyakarta: BPFE. 